www.jmscr.igmpublication.org

Impact Factor 5.84

Index Copernicus Value: 83.27

ISSN (e)-2347-176x ISSN (p) 2455-0450

crossref DOI: https://dx.doi.org/10.18535/jmscr/v5i2.157

Journal Of Medical Science And Clinical Research

\title{
A Study on Haemodialysis Vsperitoneal Dialysis in Acute \& Chronic Renal Failure
}

\author{
Authors \\ Christopher Nesamony ${ }^{1}$, Suresh Kumar ${ }^{2}$, Manivel Ganesan ${ }^{3}$ \\ ${ }^{1}$ Professor\& HOD, Dept of General Medicine, Kanyakumari Government Medical College, Kanyakumari \\ ${ }^{2}$ Post Graduate, Dept of General Medicine, Kanyakumari Government Medical College, Kanyakumari \\ ${ }^{3}$ Inntern, Dept of General Medicine, Kanyakumari Government Medical College, Kanyakumari \\ Corresponding Author \\ Dr. Suresh Kumar.P
}

Post Graduate, Dept of General Medicine, Kanyakumari Government Medical College, Kanyakumari

\begin{abstract}
Background: Over the past few decades, Dialysis has become more effective in the management of acute \& chronic renal failure and poisonings (Acute kidney injury). There are a number of studies which recommend either peritoneal or hemodialysis depending upon the clinical situations, facilities available and other factors. In clinical usage, the waste materials in the blood are filtered through the Semi permeable membranes and thus separated from the body. Semi permeable membrane could be natural as peritoneum or artificial as in the artificial kidney (dialyser). Thus, there are two modes of Dialysis namely Peritoneal and hemodialysis.

Materials and Methods: All the patients who have undergone Hamodialysis and peritoneal dialysis in Kanyakumari Government Medical College, General Medicine Department during the period from Jan 2015 to Jan 2017 were included in this study. All the patients were analyzed clinically and biochemically before taking for dialysis. Each dialysis sessions were watched carefully for complications. The aim of study is to find out the value of Dialysis in various medical disorders namely acute renal failure, chronic renal failure and poisoning \& to find out the incidence and types of complications in peritoneal and hemodialysis \& to compare the advantages and disadvantages of peritoneal dialysis and hemodialysis in various age groups and various disorders.

Observation and Results: In this study, a total of 742 patients who have undergone 1035 sessions of peritoneal dialysis and 839 sessions of hemodialysis were studied.601 peritoneal dialysis (males -394 \& females -207) patients and 205 hemodialysis (males -133 \& females -72) patients were analyzed. In this, 537 patients had undergone only peritoneal dialysis, 141 patients hemodialysis alone and 64 patients both hemodialysis and peritoneal dialysis. Complications of $12.51 \%$ \& $19.7 \%$ occurred in patients who had undergone hemodialysis and peritoneal dialysis, respectively.

Conclusion: Dialysis was valuable in prolonging the life of CRF patients $44.69 \%$ of HD and $41.68 \%$ of PD patients.) Mortality during hospital stay was 7.06\%. 10 patients went to transplantation. Dialysis was valuable in the management of dialysable poisons (1.05\% of HD and $3.4 \%$ of PD in Patients). In HD, No death was recorded. In PD, death was $14.28 \%$.
\end{abstract}

Keywords: Acute \& chronic renal failure, Poisonings (Acute kidney injury), Dialysis. 


\section{INTRODUCTION}

Dialysis is a Greek word given by Scottish Chemist Robert Graham which signifies "Loosening" or "Disintegration". Hemodialysis was first done by WillenKolf in 1947. Later discoveries and wide application of arteriovenous shunt by Quinton et al $1960^{1}$ procedure of hemodialysis revolutionized the dialysis procedure.Peritoneal dialysis was conceived by Putnam $^{1}$ in 1923 and first applied by Genter during the same period for the treatment of potentially reversible acute renal failure. Subsequent workers as Abbot et al 1946, Fine et al 1946 and Grellman et al 1951 gained further experience in its application. The choice of either hemodialysis or peritoneal dialysis depends upon the patients - age, facilities available, specific clinical problems and the distance from the medical care center.

\section{INDICATIONS FOR DIALYSIS}
A) Uraemia $\left(\mathrm{ARF}^{8} / \mathrm{CRF}\right)$

Both for peritoneal Dialysis and Hemodialysis.

1. Hyper Kalaemia> $6.5 \mathrm{MEq} / \mathrm{L}^{1}$

2. Severe acidosis $\mathrm{PH}<7.15^{13}$

3. Pulmonary oedema.

4. Blood Urea $200 \mathrm{MG} / 100 \mathrm{ml}^{1}$

5. Daily rise of Blood Urea $>70 \mathrm{mg} / 100 \mathrm{ml}$ day.

6. Pericarditis ${ }^{14}$

7. Creatinine Clearance persistently less than $5 \mathrm{ml} / \mathrm{min}$.

(B). Indications other than Uraemia:
1. Interactable Fluid removal
Pulmonary
oedema $^{14}$ of
Cardiac
Origin

2. Hepatic

Coma

Corrects fluid, electrolyte and removal of ammonia and Bilirubin
3. Hyperuricemia Removal of excess of Uric acid
4. Hyper
Removal of excess of
Calcaemia
Calcium
( $\mathrm{Sr}$ Calcium >
$11 \mathrm{mg} \%$ ) drugs Phenobarbitone, heavy metals, Bromide etc.
5. Poisons and Eg. Salicylates,
6. Rarely Acute Unknown metabolites pancreatitis ${ }^{15}$ Are removed.

Peritoneal Dialysis to preferable in - Children, Old patient, Cardio vascular diseases ${ }^{16}$, peritonitis, heparin contraindicated situations, restricted vascular access, patient refusing H.D., non availability of H.D. and in emergency.

Haemodialysis is preferable in,Hyper-catabolic state $^{17}$,marked obesity, acute and chronic chest diseases, poisoning, non-availability of P.D. fluid and recent abdominal surgery ${ }^{18}$.

\section{MATERIAL AND METHODS}

All the patients who have undergone Hamodialysis and peritoneal dialysis in Kanyakumari Government Medical College, General Medicine Department during the period from Jan 2015 to Jan 2017 are included in this prospective study.

All the patients were analyzed clinically and biochemically before taking for dialysis. Each dialysis session was watched carefully for complications.

601 peritoneal dialysis patients and 205 hemodialysis patients were analyzed. Of this, 537 patients had undergone only peritoneal dialysis, 141 patients hemodialysis alone and 64 patients both hemodialysis and peritoneal dialysis. In total, 742 patients who have undergone 1035 sessions of peritoneal dialysis and 839 sessions of hemodialysis were studied.

Patients with hyperkalaemia $\left(\mathrm{Sr} \mathrm{K}^{+}>6.5 \mathrm{mEq} / \mathrm{L}\right.$, tall ' $\mathrm{T}$ ' waves in ECG), pulmonary edema, rapid rise of blood urea, high creatinine level, with acidotic breathing and clinical evidence of pericarditis and also patient consumed dialyzable poisons were taken for either peritoneal dialysis 


\section{JMSCR Vol||05||Issue||02||Page 18212-18224||February}

(or) hemodialysis depend upon the availability of materials, facilities and the condition and specific problems of the patient.

For hemodialysis vascular access was either femoral (or) subclavian (or) A.V.Shunts. Hollow fibre dialyzer was used with acetate dialysate. Flow rate usually $200 \mathrm{~m} / \mathrm{min}$ and hemodialysis time was 3 to 4 hours.

For peritoneal dialysis after emptying bladder, under strict aseptic precautions under local anaesthesia, at the elective site usually midline or slightly lateral points about 1" -2 " away from the umbilicus, catheter fitted with stylet\& perforated and was introduced about $15 \mathrm{~cm}$ intraabdominally directed towards one of the iliac fossa. Dialysis fluid used here usually contains
Sodium 130mEq/L, Calcium $3 \mathrm{mEq} / \mathrm{L}$, Magnesium $1.5 \mathrm{mEq} / \mathrm{L}$, with Dextrose Anhydrous 1.7 gm. And Sod. Meta Bi Sulphite 0.015 gm.

Usually one exchange 1000 to $1500 \mathrm{ml}$.

Children $50 \mathrm{ml} / \mathrm{kg}$ body wt.

Heparin 250 I.U. on alternative exchanges.

Dwell Time $\quad$ - $\quad 30$ minutes

Total exchanges - $\quad 20$ (Minimum)

The session _ $\quad$ - 24 to 48 hours

Each session of P.D. and H.D. were carefully studied to know the indications, complications and outcome and comparative study of peritoneal and hemodialysis was done.

\section{OBSERVATION AND RESULTS}

HAEMO DIALYSIS

AGE AND SEX

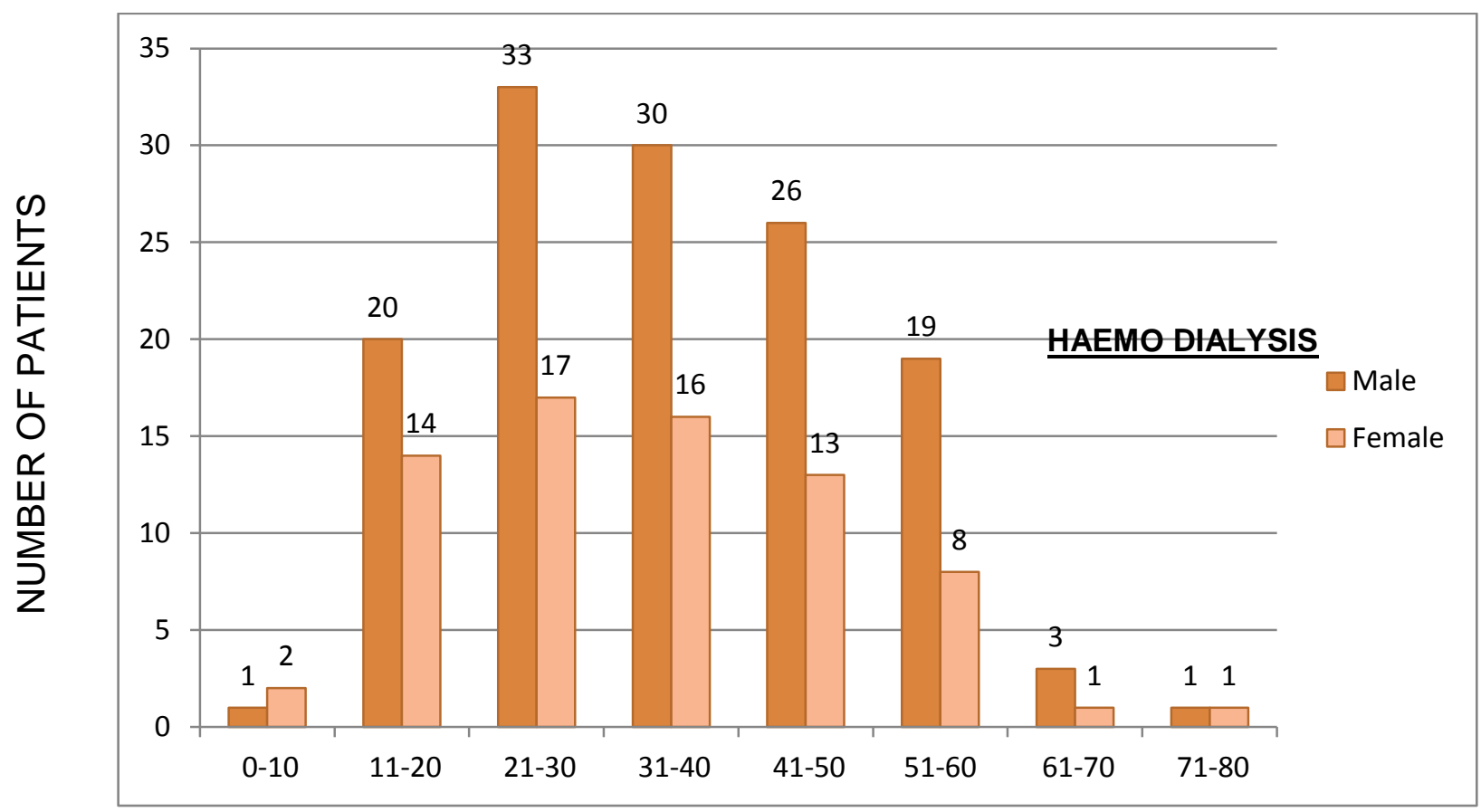

AGE OF THE PATIENTS 


\section{JMSCR Vol||05||Issue||02||Page 18212-18224||February}

HEMODIALYSIS:

\section{AGE AND SEX}

Table 1

\begin{tabular}{llll}
\hline AGE IN YEARS & MALE & FEMALE & TOTAL \\
\hline $0-10$ & 1 & 2 & 3 \\
$11-20$ & 20 & 14 & 34 \\
$21-30$ & 33 & 17 & 50 \\
$31-40$ & 30 & 16 & 46 \\
$41-50$ & 26 & 13 & 39 \\
$51-60$ & 19 & 8 & 27 \\
$61-70$ & 3 & 1 & 4 \\
$71-80$ & 1 & 1 & 2 \\
\hline Total & $\mathbf{1 3 3}$ & $\mathbf{7 2}$ & $\mathbf{2 0 5}$ \\
\hline
\end{tabular}

\section{PERITONEAL DIALYSIS}

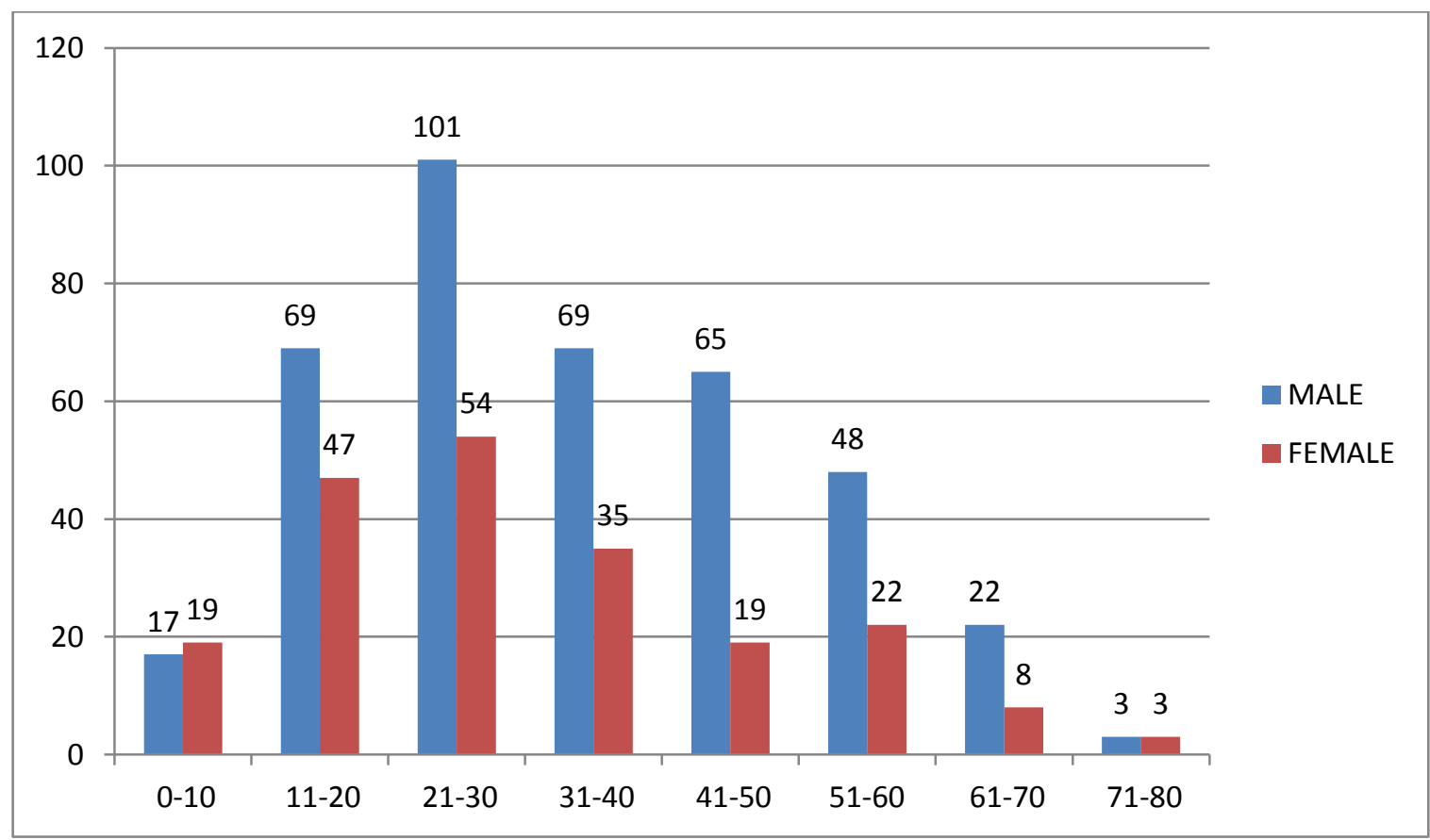

Table: 2 Peritoneal Dialysis

\begin{tabular}{llll}
\hline AGE IN YEARS & MALE & FEMALE & TOTAL \\
\hline $0-10$ & 17 & 19 & 36 \\
$11-20$ & 69 & 47 & 116 \\
$21-30$ & 101 & 54 & 155 \\
$31-40$ & 69 & 35 & 104 \\
$41-50$ & 65 & 19 & 84 \\
$51-60$ & 48 & 22 & 70 \\
$61-70$ & 22 & 8 & 30 \\
$71-80$ & 3 & 3 & 6 \\
\hline Total & $\mathbf{3 9 4}$ & $\mathbf{2 0 7}$ & $\mathbf{6 0 1}$ \\
\hline
\end{tabular}




\section{BOTH HD AND PD IN CHILDREN}

TABLE-3

\begin{tabular}{llll}
\hline AGE IN YEARS & MALE & FEMALE & TOTAL \\
\hline$<2$ & - & - & 0 \\
$2-6$ & 5 & 5 & 10 \\
$>6$ & 8 & 17 & 25 \\
\hline Total & $\mathbf{1 3}$ & $\mathbf{2 2}$ & $\mathbf{3 5}$ \\
\hline
\end{tabular}

Children form only 5.16\%

\section{PD AND HD ETOLOGY IN CHILDREN}

TABLE-4

\begin{tabular}{lcccc}
\hline \multirow{2}{*}{ ETIOLOGY } & \multicolumn{3}{c}{ AGE } \\
& $<\mathbf{2}$ & $\mathbf{2 - 6}$ & $\mathbf{> 6}$ & TOTAL \\
\hline ARF & - & 8 & 16 & 24 \\
CRF & - & 2 & 9 & 11 \\
\hline Total & & $\mathbf{1 0}$ & $\mathbf{2 5}$ & $\mathbf{3 5}$ \\
\hline
\end{tabular}

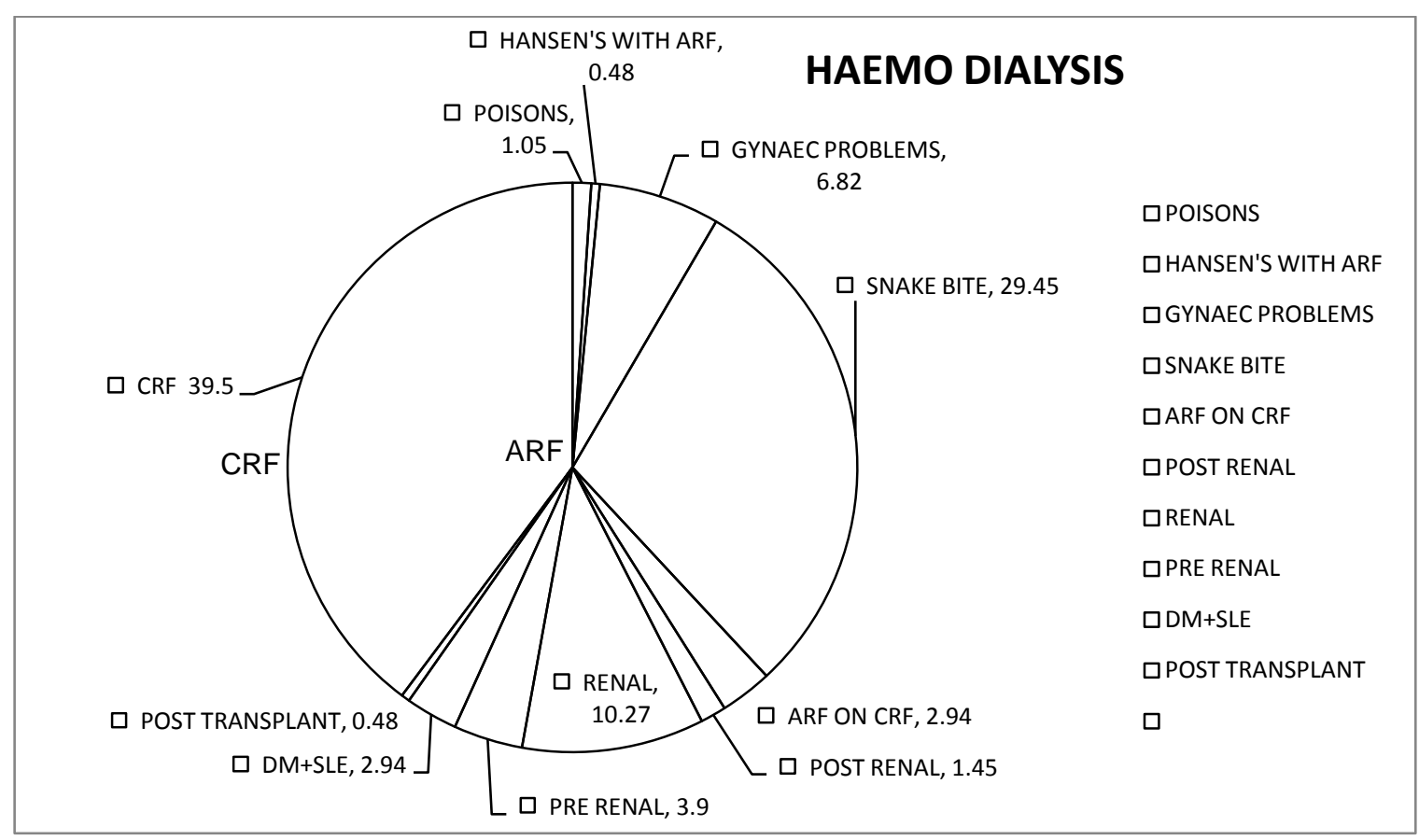

\section{ETIOLOGY HEMODIALYSIS}

TABLE-5

\begin{tabular}{lll}
\hline ETIOLOGY & NO. OF PATIENTS & PERCENTAGE \\
\hline ARF MEDICAL & & \\
TUBULAR & 68 & $32.17 \%$ \\
GLOMERULAR & 25 & $10.21 \%$ \\
INTERSTITIAL & 2 & $0.96 \%$ \\
VASCULAR & 1 & $0.48 \%$ \\
GYNAEC & 14 & $6.82 \%$ \\
SURGICAL & 3 & $1.45 \%$ \\
\hline
\end{tabular}


POISON

CRF

CRF - PRIMARY RENAL

$\mathrm{DM}+\mathrm{SLE}(4+2)$

POST TRANSPLANTATION (1)
4

81

6

1
$1.05 \%$

$39.5 \%$

$2.94 \%$

$0.48 \%$

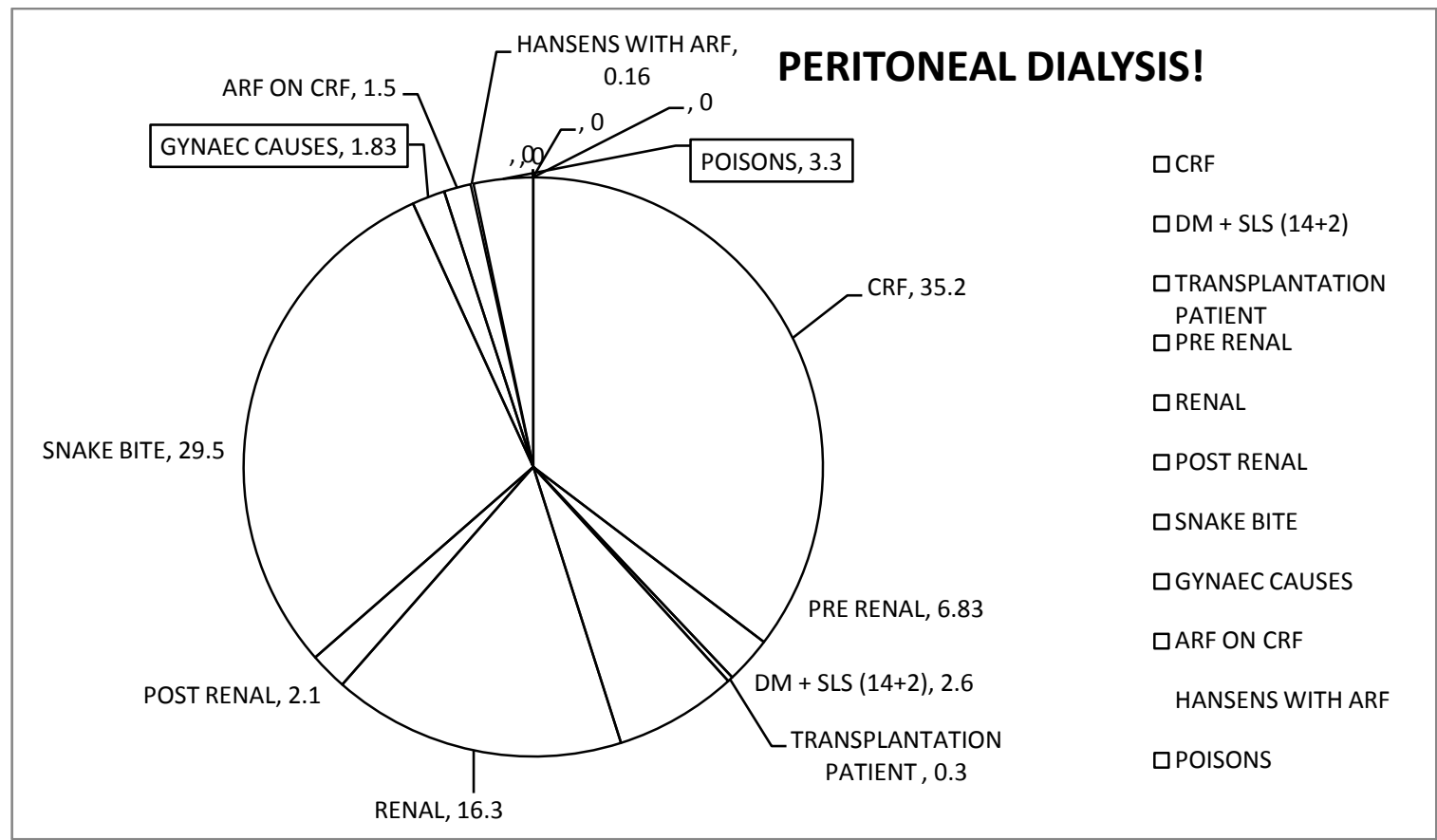

TABLE-6

COMPLICATIONS IN HEMODIALYSIS

TOTAL PATIENT: 205

TOTAL SESSIONS: 839

\begin{tabular}{llll}
\hline No. & COMPLICATIONS & $\begin{array}{l}\text { No. of } \\
\text { Times }\end{array}$ & PERCENTAGE \\
\hline 1. & DEATH DURING DIALYSIS & 3 & $1.46 \%$ of patients \\
2. & HYPOTENSION AND PALPITATION & 51 & $6.07 \%$ \\
3. & TACHYCARDIA AND & 2 & $0.23 \%$ \\
4. & HYPERTENSION & 5 & $0.59 \%$ \\
5. & RIGOR, CHILLS AND FEVER & 35 & $4.17 \%$ \\
6. & ITCHING FAILURE AND TECHNICAL & 1 & $0.12 \%$ \\
7. & POWER & 4 & $0.46 \%$ \\
8. & PROBLEM & 1 & $0.12 \%$ \\
9. & CHEST PAIN & 1 & $0.12 \%$ \\
10. & DYSPNOEA & 2 & $0.23 \%$ \\
\hline Total & HAEMORRHAGE & $\mathbf{1 0 5}$ & $\mathbf{1 2 . 5 1 \%}$ \\
\hline
\end{tabular}




\section{JMSCR Vol||05||Issue||02||Page 18212-18224||February}

\section{TABLE-7}

\section{PERITONEAL DIALYSIS}

TOTAL PATIENT: 601

TOTAL SESSIONS: 1035

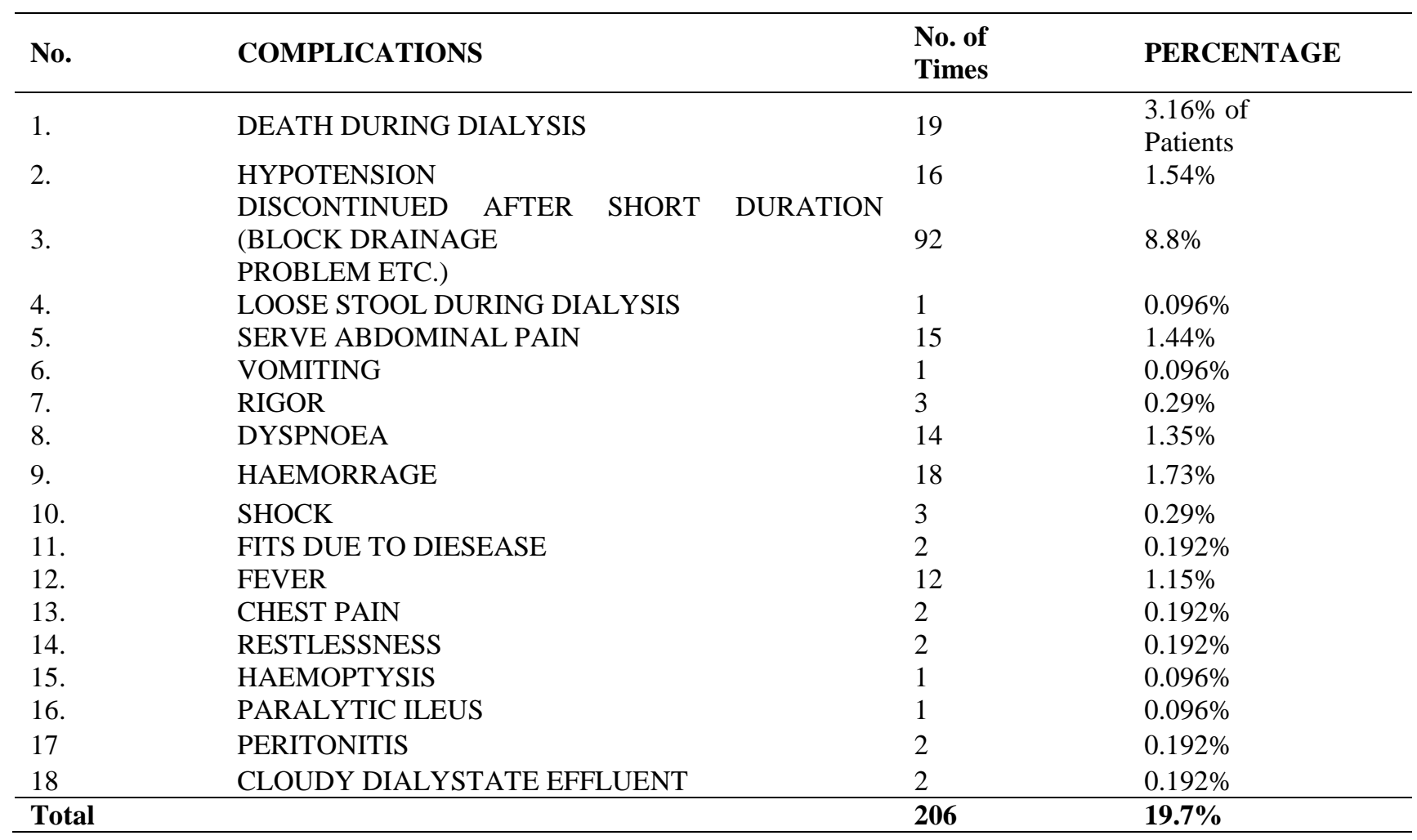

\section{SPECIFIC INDICATIONS}

\section{TABLE: 8}

HEMODIALYSIS

\begin{tabular}{|c|c|c|c|}
\hline No. & INVESTIGATIONS & $\begin{array}{l}\text { No. of } \\
\text { Patients }\end{array}$ & $\%$ \\
\hline 1. & POTASSIUM $>6$ M.eq / Lt & 12 & $5.85 \%$ \\
\hline \multirow[t]{3}{*}{2.} & BLOOD UREA $101-200 \mathrm{Mg} \%$ & 71 & \\
\hline & $201-300 \mathrm{Mg} \%$ & 19 & $44.8 \%$ \\
\hline & $>300 \mathrm{Mg} \%$ & 2 & \\
\hline \multirow[t]{3}{*}{3.} & Sr. CREATININE $\quad 10 \mathrm{Mg} \%$ & 105 & \\
\hline & $11-15 \mathrm{Mg} \%$ & 29 & $66.34 \%$ \\
\hline & $>15 \mathrm{Mg} \%$ & 2 & \\
\hline 4. & TALL ‘ $T$ ’ WAVES IN ECG & 9 & $4.3 \%$ \\
\hline
\end{tabular}




\section{JMSCR Vol||05||Issue||02||Page 18212-18224||February}

TABLE: 9

\section{PERITONEAL DIALYSIS}

\begin{tabular}{|c|c|c|c|}
\hline No. & INVESTIGATIONS & $\begin{array}{l}\text { No. of } \\
\text { Patients }\end{array}$ & $\%$ \\
\hline 1. & POTASSIUM >6 M.eq / Lt & 50 & $8.31 \%$ \\
\hline \multirow[t]{3}{*}{2.} & BLOOD UREA $101-200 \mathrm{Mg} \%$ & 228 & \\
\hline & $201-300 \mathrm{Mg} \%$ & 83 & $53.06 \%$ \\
\hline & $>300 \mathrm{Mg} \%$ & 8 & \\
\hline \multirow[t]{3}{*}{3.} & Sr. CREATININE $\quad 10 \mathrm{Mg} \%$ & 291 & \\
\hline & $11-15 \mathrm{Mg} \%$ & 88 & $64.89 \%$ \\
\hline & $>15 \mathrm{Mg} \%$ & 11 & \\
\hline 4. & TALL 'T' WAVES IN ECG & 33 & $5.4 \%$ \\
\hline
\end{tabular}

Note: Blood Urea 100-200 mg\% Not an Absolute Indication for Dialysis Rapid Increase of Urea is significant.

TABLE: 10

DIALYSIS IN POISON

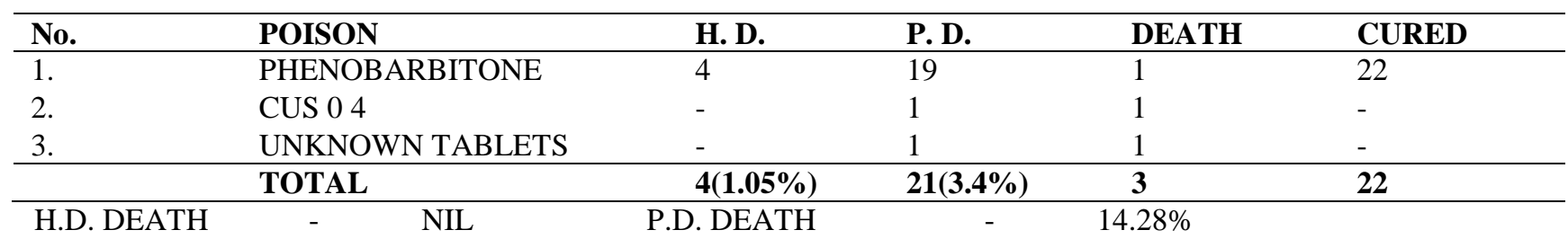

TABLE: 11

TRANSPLANTATION

PARTICULARS OF PATIENT UNDERGONE TRANSPLANTATION AFTER

\begin{tabular}{llll}
\hline & H. D. & P. D. & TOTAL \\
\hline NO. OF PATIENTS & 4 & 6 & 10 \\
& & & $(1.34 \%)$ \\
\hline
\end{tabular}

POST TRANSPLANTATION PATIENTS UNDERGONE DIALYSIS

H.D- 1.

P.D- 3.

TABLE: 12

DIABETES MELLITUS

DIABETIC NEPHROPATHY AND DIALYSIS

\begin{tabular}{llll}
\hline & H. D. & P. D. & TOTAL \\
\hline $\begin{array}{l}\text { NO. OF PATIENTS } \\
\text { OF DIABETIC }\end{array}$ & 4 & 14 & 18 \\
NEPHROPATHY & $(1.95 \%)$ & $(2.3 \%)$ & $(2.41 \%)$ \\
\hline
\end{tabular}


TABLE: 13

DIALYSIS IN SNAKE BITE-ARF DUE TO SNAKE BITE

\begin{tabular}{lllll}
\hline No. & SNAKE BITE & H. D. & P. D. & TOTAL \\
\hline 1. & NO. OF PATIENTS & 60 & 177 & 237 \\
2. & $\%$ IN ARF & $53.09 \%$ & $50.57 \%$ & - \\
3. & $\%$ IN TOTAL DIALYSIS & $29.45 \%$ & $29.5 \%$ & - \\
PATIENT & DEATH & 2 & 10 & 12 \\
5. & $\%$ & $3.3 \%$ & $5.65 \%$ & $5.06 \%$ \\
\hline
\end{tabular}

TABLE: 14

DIALYSIS IN PROBLEMS OTHER THAN MEDICAL

\begin{tabular}{llllll}
\hline No. & PROBLEMS & H. D. & P. D. & TOTAL & \% \\
\hline 1. & OBSTEITRICS AND & 14 & 11 & 25 & $3.36 \%$ \\
& GYNAECOLOGY & $(6.8 \%)$ & $(1.82 \%)$ & & OF TOTAL \\
2. & SURGICAL & 3 & 13 & 16 & $2.15 \%$ \\
& & $(1.45 \%)$ & $(2.1 \%)$ & & OF TOTAL \\
TOTAL & 17 & 24 & 41 & \\
\hline
\end{tabular}

TABLE: 15

DEATH

\begin{tabular}{|c|c|c|c|c|c|}
\hline No. & $\begin{array}{l}\text { TIME OF } \\
\text { DEATH / AMA }\end{array}$ & H. D. & P. D. & CAUSE & TOTAL \\
\hline \multirow[t]{2}{*}{1.} & DURING DIALYSIS & 3 & 19 & DUE TO & 22 \\
\hline & & $(1.46 \%)$ & $(3.16 \%)$ & $\begin{array}{l}\text { UNDERLYING } \\
\text { DIESEASE }\end{array}$ & \\
\hline \multirow[t]{2}{*}{2.} & AFTER DIALYSIS & 5 & 10 & -do- & 15 \\
\hline & & $(2.43 \%)$ & $(1.66 \%)$ & & \\
\hline \multirow[t]{2}{*}{3.} & A.M.A. IN & & 20 & & \\
\hline & SERIOUS CONDITION & - & $(3.32)$ & -do- & 20 \\
\hline \multicolumn{2}{|c|}{ TOTAL \% } & $3.89 \%$ & $8.14 \%$ & & $\begin{array}{l}7.68 \% \text { OF } \\
\text { TOTAL }\end{array}$ \\
\hline
\end{tabular}

\section{DISCUSSION}

\section{HEMODIALYSIS}

Fundamentally, heparinized blood and a physiological salt solution (or) dialysate, one perfused on opposite sides of a semipermeable membrane and solutes move from the blood to the dialysate (or) vice versa along a concentration gradient according to the molecular size.

Access of the Blood Stream:

1. Temporary Access a) Femoral access.

b) Subclavian access.

2. Permanent Access
a) External device e.g. Scribner Arteriovenous Shunt, Thomas Shunt
b) Internal device. Arteriovenous fistula by anastomosing vessels (or) grafts.
c) Combined Internal - External device eg: Hemasile.


Dialyzers:
1. The flat plate.
2. Coiled dialyzer
3. Hollow fiber

The hollow-fibre ${ }^{5}$ dialyzer is now widely used for dialysis.

\section{Dialysate:}

For Hemodialysis many different dialysate formula are available with variation in the concentration of Sodium, Potassium, Calcium and Glucose. The two widely and commonly using dialysate containing.
1. Acetate
2. Bicarbonate

\section{PERITONEAL DIALYSIS}

Peritoneal dialysis effective and simplest procedure than hemo-dialysis. It does not require specialized personnel and special installation (or) equipment. There is less transfusion requirements, less incidence of renal osteodystrophy and uraemic neuropathy. Risk of infection can be reduced with better care and prevention of bacterial intrusions.

Based on principles of Osmosis and diffusion molecule flow either side of the peritoneal dialysis membrane (comprising of capillary endothelium and peritoneal mesothelium with large number of pores) in between micro-circulation of capillaries and dialysis solution in the peritoneal cavity.

\section{Dialysis Fluid: ${ }^{20}$}

Usually comprises Sodium, Calcium, Magnesium, Chloride, Lactate and Dextrose with or without Potassium. It is sterrile ${ }^{16}$

Peritoneal Catheter ${ }^{19}$ :

1. Acute Catheter - for intermittent peritoneal dialysis.

2. Chronic Catheter - for CAPD and CCP

\section{INCIDENCE}

A statistical report about dialysis patient in U.S.A. in 1989 in the American Journal of Kidney disease $^{25}$ reveals that male predominates female (61.07 : $38.93 \%$ ), $73.60 \%$ patients more than 45 years. Children are less affected. In this study, male: Female 60.56:39.44. 75.54\% Patients less than 45 years and children $5.16 \%$, A.P. Ponday ${ }^{33}$ et al in India most of the patients are 16-40 years.

\section{INDICATIONS}

Statistics in American journal of kidney disease ${ }^{23}$, in U.S.A. in CRF, especially due to Diabetes and hypertension is the most common indication. In this study ARF predominates $(55.31 \%$ of HD and $58.32 \%$ of P.D. patients are ARF) Diabetic nephropathy only $23 \%$ of P.D. and $1.9 \%$ of H.D. patients.

Carl M. Kiellstrand ${ }^{32}$, Robert.O. Berkselt and Horst Klinkmamn in a study of 1381 patients $60 \%$ of ARF due to Acute tubular necrosis $\left(2 / 3^{\text {rd }}\right.$ due to medical problems like reduced perfusion, sepsis and toxins: $1 / 3^{\text {rd }}$ due to surgery and trauma). In this study ATN due to snake bite forms $53.09 \%$ of H.D. and $50.57 \%$ of P.D. patients. ARF due to surgical \&Gynaec problem $2.15 \%$ and $3.36 \%$ respectively.

Lt.Col. Yashpal ${ }^{1}$ and R.Gabriel ${ }^{13}$ states indication of dialysis include pulmonary oedema, Hyper Kalaemia, rapid rise of urea. In this study Dialysis done for pulmonary oedema (HD 5.26\% : PD $1.49 \%$ ), pericarditis (3.9\% of HD and $1.35 \%$ of PD), encephalopathy (HD $0.97 \%$ : PD 1.16\%) HyperKalaemia (5.85\% of HD and $8.31 \%$ of PD) and rapid rise of urea (PO 64.89\%: HD 66.34\%). Sometimes, prophylactic Dialysis is done without symptoms till recovery.

\section{COMPLICATIONS:}

\section{HEMODIAL YSIS:}

De Goulet et al ${ }^{5}$ in a study of 1,35,000 dialysis Hypotension $21.7 \%$, fever \& head ache $3.1 \%$ : Kiellstrand in 1970 hypotension $20-50 \%$ Suhailahamed $^{5}$ and Co-workers in hollow fibre dialysis hopetension 20\%. In this study, 
Hypotension $6.07 \%$, fever $4.17 \%$, Hypertension $(0.59 \%)$, and technical problem (0.46\%). Hemorrhage $(0.23 \%)$, Tachycardia and palpitation $(0.23 \%)$, Dyspnoea \& Chest pain $(0.24 \%)$.

\section{COMPLICATIONS \\ PERITONEAL DIALYSIS}

Charles M.Mion ${ }^{16}$ et al abdominal pain $3-4 \%$ Bleeding 6\%: Infection 3-5\% Col. Yashpal ${ }^{1}$ et al in a study of 1245 P.D. patients, peritonitis 69 sessions, Blocking of Cathetes 9.3\%, abdominal pain 146 sessions, Hemorrhage 41 sessions. In this study Block and discontinuation $8.8 \%$ : Severe abdominal pain $1.44 \%$ : Hemorrhage $1.35 \%$ peritonitis only $0.19 \%$ because of strict aseptic precautions and Antibiotic therapy.

\section{RELATIVE MERITS OF HEMODIALYSIS AND PERITONEAL DIALYSIS}

Lt. Col. Yashpal ${ }^{1}$ - peritoneal dialysis preferable in children. This study confirm this. Carl. M. Kiellstrand ${ }^{32} \&$ co-workers - choice is probably more technical or institutional than indicated by patient. M.J.D. Cassidy ${ }^{30}$ observation in Romania. Choice of dialysis for all renal problems is hemodialysis because of non-availability of peritoneal dialysis fluid. In this study, the choice of dialysis also depends upon availability of materials.

Edward. A. Ross ${ }^{11}$ and Co-workers showed in severely ill patients P.D. better. In this study also, P.D. is preferred.

Robert A. Gutman ${ }^{8}$ states that for rapid removal of fluid, H.D. is better. In this study, H.D. gave quick relief in pulmonary oedema.

Lt. Col. Yashpal ${ }^{1}-$ the cost of P.D. is more than H.D. in India.

Robert W. Shrier ${ }^{15}$ in "Diseases of the Kidney" stated that in cardiovascular impairment, P.D. is preferred and respiratory impairment H.D. is preferred. We also arrive at same conclusion through this study.

William J.C. Amend ${ }^{21}$ and Co-workers - there is reduced molecular clearance in P.D. In this study, H.D. is helpful for the quick removal of poisons
(Death rate in H.D. is Nil; but in P.D. death rate is 14.28\%).

Eli. A friedman ${ }^{5}$ et al study shows mortality rate of dialysis patient $19 \%$. William J.C. Amend ${ }^{21}$ and Co-workers - mortality rate in U.S. is $8.10 \%$. In this study mortality rate is $7.68 \%$. Cause of mortality was due to the underlying diseases.

Kjellstrand $^{32}$ and Co-workers stated 68\% mortality in Acute Tubular necrosis (ATN). In this study, snake bite ${ }^{15}$ - one of the commonest causes of ATN - death rate is only $5.06 \%$. So here value of Dialysis, in ARF patient due to snake bite is firmly established.

\section{CONCLUSION}

The value of dialysis was more in ARF patients (55.31\% of HD and $58.32 \%$ of PD patients) in whom conservative management was ineffective. Mortality rate was only $2.83 \%$ of dialysed patients. Among ARF 53.09\% of HD and 50.37\% PD patients were due to snake bite (237 patients) in whom mortality rate was only $5.06 \%$.

Dialysis was valuable in prolonging the life of CRF patients $(44.69 \%$ of $\mathrm{HD}$ and $41.68 \%$ of PD patients.) Mortality during hospital stay was 7.06\%. 10 patients progressed to transplantation.

Dialysis was valuable for the management of dialysable poisons $(1.05 \%$ of $\mathrm{HD}$ and $3.4 \%$ of PD Patients) In HD No death, but in PD $14.28 \%$.

The common complication in hemodialysis were Hypotension (6.07\%) Rigor, Chills and fever (4.17\%), Hypertension (0.59\%), technical problems $(0.46 \%)$, Hemorrhage $(0.23 \%)$, Tachycardia and palpitation $(0.23 \%)$, Dyspnonea\& Chest pain $(0.24 \%)$ and itching $(0.12 \%)$.The common complications in peritoneal dialysis were catheter block and premature discontinuation (8.8\%), Haemorrhage (1.73\%), Hypotension (1.54\%), Severe abdominal pain $(1.44 \%)$, Dysponea $(1.35 \%)$, Fever and rigor (1.24\%), Shock (0.29\%), Cloudy dialysate effluent $(0.19 \%)$ and other complications like vomiting, loose stool during dialysis, Fits, Chest pain, Restlessness, Haemoptysis, and paralytic ileus $(0.96 \%)$. Peritonitis was about only $0.192 \%$. 
Peritoneal Dialysis was found to be better in extremes of age, decompensated Cardiac problems, emergencies, severely ill patients. It is technically an easy procedure which can be started quickly but it is costlier than H.D.

Haemodialysis was found to be preferable in severe respiratory impairement and it gave quick improvement in pulmonary oedema, metabolic acidosis, hyperkalemia and gave quick relief indisalysable poisons. Patient compliance was more than peritoneal dialysis as the duration of hemodialysis is shorter. Initial investment, use of imported materials, need of technical staff and sterilization procedures make haemodialysis relatively a difficult procedure.

\section{REFERENCE}

1. It Col. Yashpal. Peritoneal Dialysis. Progress in Clinical medicine by M.M.S. Ahuja. $5^{\text {th }}$ series Page $352-366$.

2. S.T. BOEN - The evaluation of peritoneal dialysis - Peritoneal dialysis by Robert.C.Atkins, Napier. M. Thomson, Peter.C.Farrel. Chap.1. P.3 - 9.

3. Christiana. M. Comty and Allan.J. CollinsDialytic therapy in the management of Chronic renal failure - Renal disease The medical clinics of North America. Vol. 68. No.2 P.P. 399 - 425

4. Charles. B. Carpenter. J. Michael Lazarus Dialysis and Transplantation in the treatment of renal failure. Harrison's principles of internal medicine Vol.II. Page $1157-1166$ (12 ${ }^{\text {th }}$ edition).

5. Suhal Ahamed, Christopher. R.Blagg, Belding. H. Sailer - Center and home hemodialysis - diseases of the kidney Vol III. By Robert. W. Shrier Page 3281 3322.

6. John. C. Vanstone M.D. - Hemodialysis current Nephrology.Vol II Chap.10. P.361 $-391$.

7. James.F.Winchester - Chronic renal failure - Conn's current therapy - Rackel 1986 - P.562 - 563.
8. Robert. A. Gutman - Acute renal failure. Indications for Dialysis - Conn's current Therapy Rackal P.558.

9. Robers. S. Brown - Dialysis - Year book of medicine Chap.50 P. 675 - 681 .

10. Karl. P. Nolph Vol. II.Current Nephrology Chap. 9. P.317 - 354.

11. Edward. A. Ross, Allen. R. Nessenson Vol. III. Nephrology - current medicine. Chap.4. P.90 - 94.

12. Steward. Cameron - "Dialysis" - "The artificial Kidney" - Kidney disease the facts. P. $182-193$.

13. R.gabriel - Management of acute renal failure chap.113. Text book of Gastro uUrinary surgery by H.N. Whitfield and W.F. Hendry. Vol. II.

14. Bruce. A. Molitoris, Robert. W. Schrier Etiology, Ppathogenesis and management of renal failure - chap.59. Vol.III. Campbell's Urology.

15. Joh. L. Cameron - Acute pancreatitis peritoneal dialysis as therapy - cConn's current therapy - Rackel - P.415.

16. Charles. M. Mion - continuous Ambulatory peritoneal Dialysis and continuous cyclic peritoneal dialysis Diseases of the Kidney edited by Roberts. W. Schrier. Vol.III. P.3235 - 3279.

17. John Blandy - Renal failure - Chap.13. Lecture note son Urology, $3^{\text {rd }} \mathrm{Ed}$.

18. T.H. Mathew - Comparison of peritoneal and hemodialysis in ARF. Peritoneal Dialysis. Chap.8. P.80 - 86. (Churchill Livingstone Publication)

19. D.F. Scott and V.C. Marshall. Insertion and complications of Tenchhoffe Catheters - Peritoneal dialysis - Chap.6. P. 61-72.

20. M.K. Mani - Dialysis. A.P.I. Text book of medicine- Revised. P.707 to 709.

21. William J.C. Amend and FlavioVincenti Chronic renal failure and Dialysis General Urology - Donald R. smith $9^{\text {th }}$ Edition. 
22. M. Yaqoob, P.Mc.Chelland and R.Ahamed - Delaymed recovery of renal function in patients with ARF due to accelerated hypertension. Post graduate medical journal .p 67, $820-832$.

23. Incidence of ESRD - Vol. XVIII No.5. Supl.PP 30-37. American Journal of Kidney diseases.

24. Beat - VolAlbertini, Juan P. Borch - short hemodialysis American Journal of nephrology. 11: 169-173.

25. Vol.XVIII. No.5. Suppl. 2. PP. 9-16. American Journal of Kidney Diseases.

26. Lionell. V. Mailloux and others. Vol.XVIII. No.3.PP. 326-335. Mortality in Dialysis patients - American Journal of Kidney Diseases.

27. J.J.B. Petrice and M.Wright - peritoneal access in ARF - Peritoneal dialysis by Robert. C. Atkins. Chap.7. P.73-79.

28. John. D.Roziah and others - Dialysis induced alteration in LV filling mechanism and clinical significance. American Journal of Kidney Diseases. Vol.XVII. No.3: P.277 - 285.

29. David. M. Spiegel and others Determinants of survival and recovery in Acute renal failure patients dialysed in intensive care unit. A.M.J. Nephrology.p 44-47.

30. M.J.D. Cassidy - Romania - Hemodialysis - The Lancer Vol.337.

31. A.C. Kennedy - maintenance Dialysis renal disease $4^{\text {th }}$ Edition by Sir. Douglas Black and N.F. Jons P.523 - 548.

32. Carl. M. Kjellstrand, Robert. O. Berkseth\& Horst Klinkmann. Treatment of ARF. Chap.VIII. P.1501 - 1540. Volume II Diseases of the Kidney by Shrier.

33. A.P.Pondey - Renal Transplantation progress in clinical medicine - series 4 by Ahuja. 